\title{
Immobilization of Lead from Pb-Contaminated Soil Amended with Peat Moss
}

\author{
Seul-Ji Lee, ${ }^{1,2}$ Myoung-Eun Lee, ${ }^{1,2}$ Jae Woo Chung, ${ }^{1,2}$ \\ Jin Hee Park, ${ }^{3}$ Keun Young Huh, ${ }^{2,4}$ and Gee-Ill Jun ${ }^{1,2}$ \\ ${ }^{1}$ Department of Environmental Engineering, Gyeongnam National University of Science and Technology (GNTECH), \\ Jinju 660-758, Republic of Korea \\ ${ }^{2}$ Green Technology Institute, GNTECH, Jinju 660-758, Republic of Korea \\ ${ }^{3}$ Centre for Mined Land Rehabilitation, The University of Queensland, St. Lucia, QLD 4072, Australia \\ ${ }^{4}$ Department of Landscape Architecture, GNTECH, Jinju 660-758, Republic of Korea
}

Correspondence should be addressed to Jae Woo Chung; jwchung@gntech.ac.kr

Received 30 May 2013; Revised 31 July 2013; Accepted 2 August 2013

Academic Editor: Daryoush Afzali

Copyright @ 2013 Seul-Ji Lee et al. This is an open access article distributed under the Creative Commons Attribution License, which permits unrestricted use, distribution, and reproduction in any medium, provided the original work is properly cited.

\begin{abstract}
Immobilization of lead $(\mathrm{Pb})$ using soil amendments can reduce $\mathrm{Pb}$ toxicity and bioavailability in soil. This study evaluated $\mathrm{Pb}$ immobilization in a $\mathrm{Pb}$-contaminated soil by using peat moss through various tests. The $\mathrm{Pb}$-contaminated soil $\left(2000 \mathrm{mg} \mathrm{Pb} \cdot \mathrm{kg}^{-1}\right)$ was amended with $1 \%, 5 \%$, and $10 \%$ of peat moss to immobilize $\mathrm{Pb}$ in the soil. The immobilization properties of $\mathrm{Pb}$ in the contaminated soil were evaluated by a column leaching experiment, a microcosm test, and a batch incubation test. Peat moss significantly reduced the $\mathrm{Pb}$ leaching in all of the experiments and more effectively reduced mobility and toxicity of $\mathrm{Pb}$ in the column leaching and microcosm tests than bioavailability in the batch incubation test. The immobilized lead from the soils amended with $1 \%, 5 \%$, and $10 \%$ of peat moss was $37.9 \%, 87.1 \%$, and $95.4 \%$ from the column leaching test, $18.5 \%, 90.9 \%$, and $96.4 \%$ from the microcosm test, and $2.0 \%, 36.9 \%$, and $57.9 \%$ from the $\mathrm{NH}_{4} \mathrm{NO}_{3}$ extraction method, respectively, indicating that peat moss can be effectively used for the remediation of $\mathrm{Pb}$-contaminated soil.
\end{abstract}

\section{Introduction}

Health authorities in many parts of the world have become increasingly concerned about the effects of heavy metals on the environment and human health and their potential implications to the international trade [1]. It is a global urgency to ensure that the heavy metal concentration of foodstuffs produced complies with the regulatory standards of other countries. Heavy metals released into the ecosystem accumulate in plants and animals and may finally result in potential health risk to humans $[2,3]$. A major source of heavy metals in the human food chain is plants grown in contaminated soil. With greater public awareness of the effects of contaminated soil on the ecosystem and human health, the scientific community and regulatory agencies have shown increasing interest in the development of effective technologies to remediate contaminated sites.

Activities such as mining, smelting, and disposal of industrial wastes have contaminated soil and water resources with heavy metals such as $\mathrm{Pb}, \mathrm{Cd}$, and $\mathrm{Zn}$ in many parts of the world $[4,5]$. The $\mathrm{Pb}$-contaminated soil can give rise to serious problems. In humans, $\mathrm{Pb}$ exposure can lead to an acute and chronic toxicity depending on the level and duration of exposure, even though acute toxicity is actually a rare condition [6]. High levels of $\mathrm{Pb}$ exposure may cause problems in the synthesis of hemoglobin, compromise the kidneys, gastrointestinal tract, joints, and the reproductive system, and result in an acute or chronic damage to the nervous system $[7,8]$.

Various remediation technologies such as soil washing, soil flushing, electrokinetic process, phytoremediation, and stabilization/solidification have been used to reduce the adverse effects of heavy metal-contaminated soils [9]. Among these remediation technologies, physicochemical technologies, including separation and removal methods, often take a long time and consume a great deal of energy when trying to meet the cleanup goals. An economical and effective alternative is in situ immobilization by use of organic adsorbents, 
which can reduce human exposure to heavy metals. Organic soil amendment can improve the soil properties for plant growth by providing nutrients as well as immobilizing heavy metals [10]. Heavy metals can be immobilized by sorption and precipitation with soil amendments [11, 12]. It has been reported that bark, chitosan, zeolite, clay, fly ash, rice bran, and peat moss are some examples of low-cost adsorbents for heavy metal immobilization $[13,14]$. Although organic adsorbents do not remove heavy metals from the soil, they can reduce the mobility and dispersion of heavy metals [15].

Peat moss is the partly carbonized remains of various mosses of the genus Sphagnum, yellowish-brown to brown and composed of more than $90 \%$ of organic matter. Peat moss helps the soil by providing organics and nutrients, preventing the soil from hardening, and improving the water holding capacity of the soil. In addition, it helps to mitigate excess salt accumulation and buffer $\mathrm{pH}$, thereby providing effective reclamation of the soil $[16,17]$. Peat mainly contains lignin and cellulose, which have polar functional groups, such as alcohols, aldehydes, ketones, acids, phenolic hydroxides, and ethers. These functional groups can participate in chemical bonding, and therefore peat moss is regarded as an effective adsorbent for the removal of heavy metals [14].

This study evaluated $\mathrm{Pb}$ immobilization in a Pb-contaminated soil by using peat moss. Although there have been a number of studies about the application of peat moss for the removal of heavy metals in wastewater, only a limited number of studies on heavy metal immobilization in contaminated soils using peat moss have been presented $[18,19]$. In this study, the effects of peat moss on the immobilization of $\mathrm{Pb}$ in the $\mathrm{Pb}$-contaminated soil were investigated through various tests. A column leaching experiment was carried out to determine the leaching potential of $\mathrm{Pb}$ in a peat moss-amended $\mathrm{Pb}$ contaminated soil; a microcosm test was conducted to evaluate heavy metal toxicity to plants and soil organisms; a batch incubation test was carried out to investigate the amount of bioavailable $\mathrm{Pb}$ after the $\mathrm{Pb}$ immobilization.

\section{Materials and Methods}

2.1. Soils Characterization and Preparation of Pb-Spiked Soil. $\mathrm{A} \mathrm{Pb}$-spiked soil was used in this study. The soil used for spiking was collected from an uncontaminated site. The soil texture was measured by particle size analysis (PSA) and classified according to the U.S. Department of Agriculture (USDA) criteria. The collected soil was air-dried, sieved to smaller than $2 \mathrm{~mm}$ using a 10-mesh sieve, and then stored in plastic bags. The soil sample was analyzed for physicochemical properties such as $\mathrm{pH}$, electrical conductivity (EC), water holding capacity (WHC), organic matter (OM) content, cation exchange capacity (CEC), and total and $\mathrm{NH}_{4} \mathrm{NO}_{3}$-extractable $\mathrm{Pb}$ concentrations. Soil $\mathrm{pH}$ and $\mathrm{EC}$ were determined in a soil : water $=1: 5(\mathrm{w} / \mathrm{v})$ suspension by using a $\mathrm{pH}-\mathrm{EC}$ meter (P25, Istek, Korea). The soil maximum WHC was measured using the Grant method [20]. Soil OM content was determined by the loss-on-ignition method [21]. The CEC of the soil was determined by the $1 \mathrm{M} \mathrm{NH}_{4} \mathrm{OAc}$ extraction method ( soil : water $=1: 10, \mathrm{pH}=7$ ). For the total heavy metal content,

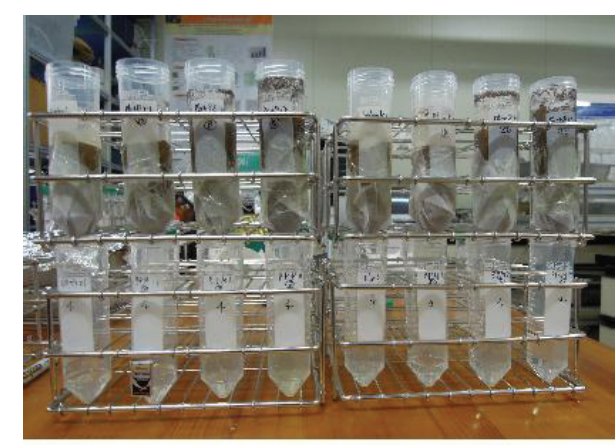

FIGURE 1: Experimental apparatus of column leaching test.

$1.5 \mathrm{~g}$ of air-dried soil was weighed into a Teflon-coated graphite block digestion system (OD-98-002, Korea), and $7 \mathrm{~mL}$ of $\mathrm{HNO}_{3}$ and $21 \mathrm{~mL}$ of $\mathrm{HCl}$ were added, and then, the mixture was shaken at $105^{\circ} \mathrm{C}$ for 2 hours. To measure the extractable $\mathrm{Pb}$ concentration, $5 \mathrm{~g}$ of the soil sample was extracted for 2 hours using $12.5 \mathrm{~mL}$ of $1 \mathrm{M} \mathrm{NH}_{4} \mathrm{NO}_{3}$ solution in a shaking incubator (KSI-200FL, KOENCON, Korea) [4].

The soil was spiked with $\mathrm{Pb}$ to $\mathrm{a} \mathrm{Pb}$ concentration of $2000 \mathrm{mg} \cdot \mathrm{kg}^{-1}$ using a $\mathrm{Pb}\left(\mathrm{NO}_{3}\right)_{2}$ solution. One $\mathrm{kg}$ of the soil was mixed with $1 \mathrm{~L}$ of $2000 \mathrm{mg} \cdot \mathrm{L}^{-1} \mathrm{~Pb}\left(\mathrm{NO}_{3}\right)_{2}$ solution in a plastic bag. And then a drying and watering procedure with manual mixing was repeated three times. The $\mathrm{Pb}$-spiked soil was amended with $1 \%, 5 \%$, and $10 \%$ of peat moss and incubated for 14 days at $37^{\circ} \mathrm{C}$. The soils were kept moist at $60 \%$ of WHC. The peat moss was purchased from Demetra (Russia), dried, and used without having been activated. The OM content of the peat moss was $93 \%$, and the elements composition measured by an element analyzer (Flash 2000 series, Perkin Elmer, USA) consisted of $70 \%$ carbon, $6 \%$ hydrogen, $0.7 \%$ nitrogen, and $0.5 \%$ sulfur.

2.2. Leaching Experiments. Three types of leaching experiments such as column leaching test, microcosm test, and batch incubation test were conducted. The column leaching test was conducted using $50 \mathrm{~mL}$ polyethylene columns $(3 \mathrm{~cm}$ in diameter and $7.5 \mathrm{~cm}$ in height). The columns were filled with $30 \mathrm{~g}$ of $\mathrm{Pb}$-spiked soils amended with $1 \%, 5 \%$, and $10 \%$ of peat moss, respectively. The columns were leached with $1 \mathrm{mM}$ of $\mathrm{CaCl}_{2}$ solution adjusted to $\mathrm{pH} 5.4$ at a flow rate of $20 \mathrm{~mL} \cdot \mathrm{h}^{-1}$ using peristaltic pumps. The $\mathrm{pH}$ of the solution was adjusted to mimic the $\mathrm{pH}$ of acid rain. $\mathrm{CaCl}_{2}$ concentration was set to $1 \mathrm{mM}$ to prevent the blocking of soil pores by the dispersion of soil particles according to the leaching method of Schwab et al. [22]. Flow rate was determined from the properties of the soil placed in the column, which was optimized to prevent pending in the column. The columns were leached for 10 pore volumes, and leachate sample was collected per pore volume. Figure 1 shows the experimental apparatus used for the column test to evaluate $\mathrm{Pb}$ leaching potential in the peat moss-amended soil.

The microcosm test was conducted by using plastic pots. Plastic pots $(600 \mathrm{~mL}$ capacity; $10 \mathrm{~cm}$ diameter $)$ were filled with $300 \mathrm{~g}$ of $\mathrm{Pb}$-spiked soil samples amended with $1 \%, 5 \%$, 


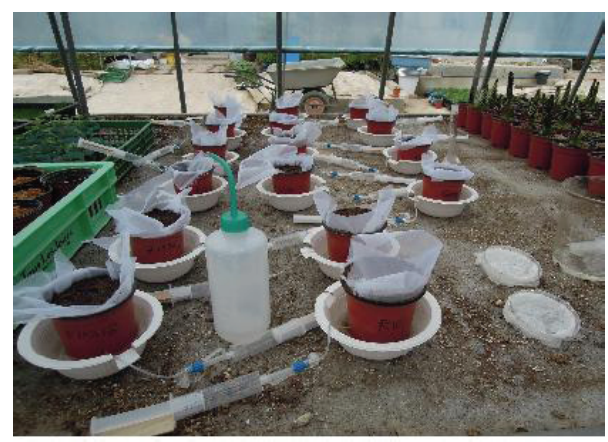

FIGURE 2: Experimental apparatus to collect pore water from microcosm test.

and $10 \%$ of peat moss, respectively. Rhizon samplers (Rhizosphere Research Products, Wageningen, Netherlands) were placed horizontally $2.5 \mathrm{~cm}$ from the bottoms of the pots, respectively. The pots were placed on plastic saucers to prevent leachate draining from the soils, and the test was carried out in a temperature-controlled greenhouse $\left(25 \pm 3^{\circ} \mathrm{C} ; 12\right.$ hours light). Figure 2 shows the experimental setup for collecting pore water from the pot test. Soil moisture content was kept at $60 \%$ of WHC. The soil was allowed to equilibrate for 7 days, and then additional water was added from the saucer to compensate for the moisture loss due to evaporation. Pore water samples were collected, using the rhizon samplers every 7 days for 35 days after the pot experiment was set up, and used for analyzing $\mathrm{Pb}$ concentration.

A batch incubation test was conducted to evaluate the bioavailable $\mathrm{Pb}$ using the $1 \mathrm{M} \mathrm{NH}_{4} \mathrm{NO}_{3}$ extraction method, in which $\mathrm{NH}_{4} \mathrm{NO}_{3}$ has been used as an indicator of bioavailability and/or phytoavailability of heavy metals [23,24]. Three grams of air-dried soil samples amended with $1 \%, 5 \%$, and $10 \%$ of peat moss, respectively, were put into $50 \mathrm{~mL}$ tubes and extracted with $1 \mathrm{M} \mathrm{NH}_{4} \mathrm{NO}_{3}$ solution (soil : solution = $1: 2.5$ ) for 2 hours in a shaking incubator.

2.3. Analytical Methods. All experiments were carried out in triplicates, and the results were compared with those of the control soil, which used $\mathrm{Pb}$-spiked soil without peat moss amendment. All the samples were filtered with a $0.45 \mu \mathrm{m}$ filter (Advantec, Japan) before the analysis. Concentrations of metal ions were analyzed by Inductively Coupled Plasma Optical Emission Spectroscopy (ICP-OES, 5300DV, Perkin Elmer, USA). The data in tables and figures are the average of triplicates, and the error bar indicates the standard deviation of the triplicates.

\section{Results and Discussion}

3.1. Soil Characterization. Various physicochemical properties of the soil were examined. The texture of the soil was loamy sand according to the United States Department of Agriculture (USDA) criteria containing sand more than $85 \%$. The $\mathrm{pH}$ and EC of the soil were 4.97 and $0.035 \mu \mathrm{S} \cdot \mathrm{cm}^{-1}$, respectively. The maximum $\mathrm{WHC}$ and $\mathrm{OM}$ content were $34 \%$ and $5.58 \%$, respectively. The CEC of the soil was

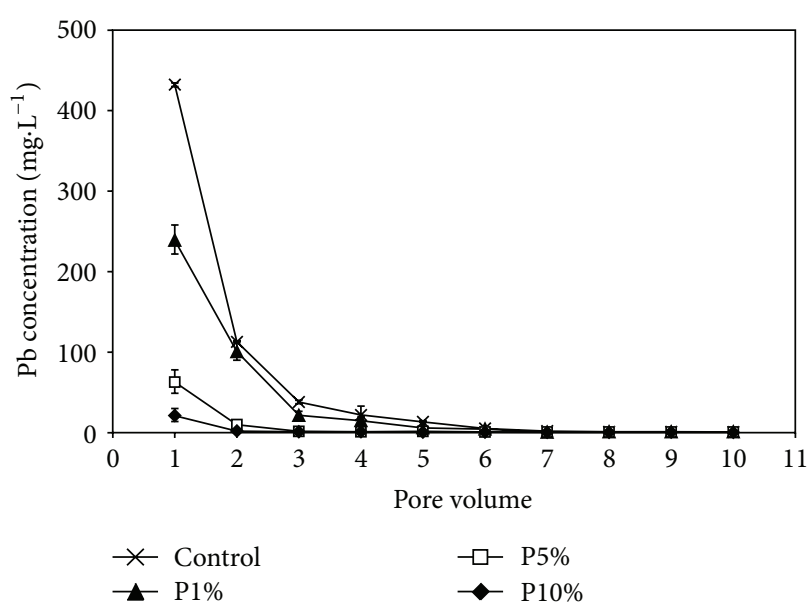

FIGURE 3: $\mathrm{Pb}$ concentration in the leachate from $\mathrm{Pb}$-contaminated soils amended with peat moss through the column leaching experiment (control: $\mathrm{Pb}$-contaminated soil without peat moss, $\mathrm{P} 1 \%$ : $\mathrm{Pb}$ contaminated soil with $1 \%$ peat moss, $\mathrm{P} 5 \%$ : $\mathrm{Pb}$-contaminated soil with $5 \%$ peat moss, and $\mathrm{P} 10 \%$ : Pb-contaminated soil with $10 \%$ peat moss).

$6.49 \mathrm{cmol} \cdot \mathrm{kg}^{-1}$. The concentrations of the total $\mathrm{Pb}, \mathrm{Cu}$, and $\mathrm{Zn}$ were negligible in the soil. The total and the $\mathrm{NH}_{4} \mathrm{NO}_{3}$ extractable $\mathrm{Pb}$ concentrations were $0.4 \mathrm{mg} \cdot \mathrm{kg}^{-1}$ and $0.061 \mathrm{mg} \cdot \mathrm{kg}^{-1}$, respectively.

3.2. Column Leaching Test. The $\mathrm{Pb}$ concentrations in the leachates eluted from the $\mathrm{Pb}$-spiked soils amended with $1 \%$, $5 \%$, and $10 \%$ of peat moss and the control are compared according to the pore volume in Figure 3 . The $\mathrm{Pb}$ concentration was reduced with increasing amount of amended peat moss. The $\mathrm{Pb}$ concentration in the first pore volume of the leachate was $432.3 \mathrm{mg} \cdot \mathrm{L}^{-1}$ for the control and $239 \mathrm{mg} \cdot \mathrm{L}^{-1}$, $62.5 \mathrm{mg} \cdot \mathrm{L}^{-1}$, and $21.2 \mathrm{mg} \cdot \mathrm{L}^{-1}$ for the $1 \%, 5 \%$, and $10 \%$ peat moss-amended soils, respectively. The $\mathrm{Pb}$ concentration in the sixth pore volume was $5.2 \mathrm{mg} \cdot \mathrm{L}^{-1}$ for the control and $4.5 \mathrm{mg} \cdot \mathrm{L}^{-1}, 0.9 \mathrm{mg} \cdot \mathrm{L}^{-1}$, and $0.6 \mathrm{mg} \cdot \mathrm{L}^{-1}$ for the $1 \%, 5 \%$, and $10 \%$ peat moss-amended soils, respectively. Low $\mathrm{Pb}$ concentrations were detected after the seventh pore volume of all the peat moss-amended soils, which may be due to the sorption of $\mathrm{Pb}$ on humic fractions. Peat moss contains high contents of humic substances with the functional groups such as carboxyl, phenolic, and alcoholic, which are very effective in heavy metal sorption because they form chelating complexes $[25,26]$. The sorption of heavy metal by organic mixtures such as peat moss occurs by surface complexation reaction [27].

Figure 4 shows the cumulative $\mathrm{Pb}$ concentrations leached from the column test for 10 pore volumes. The total leached $\mathrm{Pb}$ concentration for 10 pore volumes was $314.7 \mathrm{mg} \cdot \mathrm{kg}^{-1}$ for the control, and those were $195.3 \mathrm{mg} \cdot \mathrm{kg}^{-1}, 40.7 \mathrm{mg} \cdot \mathrm{kg}^{-1}$, and $14.5 \mathrm{mg} \cdot \mathrm{kg}^{-1}$ for the $1 \%, 5 \%$, and $10 \%$ peat mossamended soils, respectively. The total leached $\mathrm{Pb}$ concentrations from soils amended with $1 \%, 5 \%$, and $10 \%$ peat moss were $62.1 \%, 12.9 \%$, and $4.6 \%$ of that from the control soil, 


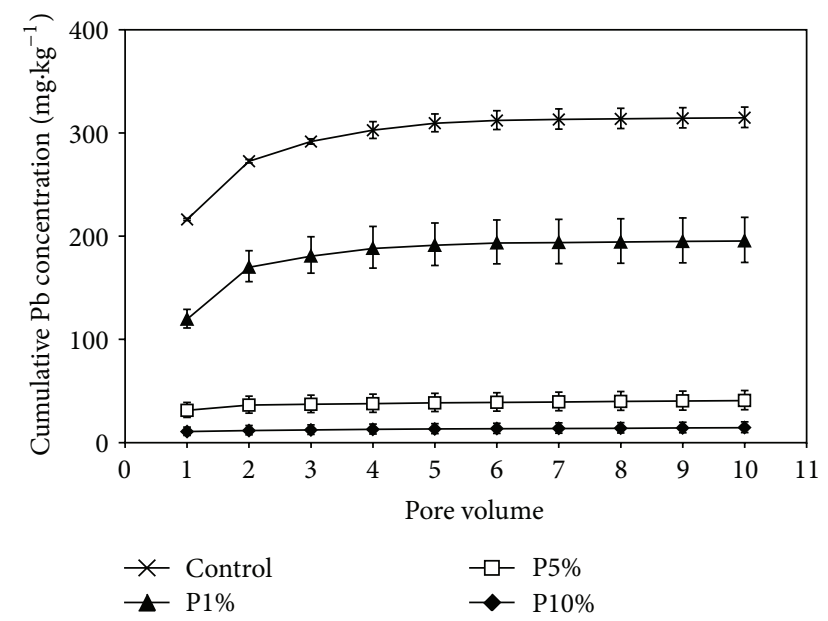

FIgURE 4: Cumulative curve of $\mathrm{Pb}$ concentration in the leachate from $\mathrm{Pb}$-contaminated soils amended with peat moss through the column leaching experiment (control: $\mathrm{Pb}$-contaminated soil without peat moss, $\mathrm{P} 1 \%$ : $\mathrm{Pb}$-contaminated soil with $1 \%$ peat moss, $\mathrm{P} 5 \%: \mathrm{Pb}-$ contaminated soil with 5\% peat moss, and $\mathrm{P} 10 \%$ : $\mathrm{Pb}$-contaminated soil with $10 \%$ peat moss).

indicating the effective immobilization of $\mathrm{Pb}$ in the soils by the peat moss.

3.3. Microcosm Test. $\mathrm{Pb}$ concentration in the pore water obtained during the microcosm test also showed the effectiveness of peat moss in immobilizing $\mathrm{Pb}$ in the soil (Figure 5). The heavy metal concentration in the pore water provides information about water-soluble metal contents, which can be exposed to plant roots or soil microorganisms, and can be used to evaluate acute metal toxicity of heavy metals $[28,29]$. The $\mathrm{Pb}$ concentration in the pore water decreased with increasing amount of peat moss. The $\mathrm{Pb}$ concentration of the soil pore water in the control was $199.5 \mathrm{mg} \cdot \mathrm{L}^{-1}$ after 7 days of incubation. The peat moss amendment significantly decreased the $\mathrm{Pb}$ concentration in the pore water. The $\mathrm{Pb}$ concentrations of the pore water samples from the soils amended with $1 \%, 5 \%$, and $10 \%$ peat moss were $190.7 \mathrm{mg} \cdot \mathrm{L}^{-1}$, $28.6 \mathrm{mg} \cdot \mathrm{L}^{-1}$, and $5.3 \mathrm{mg} \cdot \mathrm{L}^{-1}$, respectively. After 35 days of incubation, the $\mathrm{Pb}$ concentration in the pore water was reduced to $22.4 \mathrm{mg} \cdot \mathrm{L}^{-1}$ in the control, and those were $18.7 \mathrm{mg} \cdot \mathrm{L}^{-1}, 1.8 \mathrm{mg} \cdot \mathrm{L}^{-1}$, and $1.7 \mathrm{mg} \cdot \mathrm{L}^{-1}$ in the $1 \%, 5 \%$, and $10 \%$ peat moss-amended soils, respectively.

Figure 6 shows the cumulative $\mathrm{Pb}$ concentrations of the pore water from the microcosm test of 35 days. After 35 days, the cumulative $\mathrm{Pb}$ concentration of the pore water was $30.7 \mathrm{mg} \cdot \mathrm{kg}^{-1}$ for the control, and those of the pore waters were $25 \mathrm{mg} \cdot \mathrm{kg}^{-1}, 2.8 \mathrm{mg} \cdot \mathrm{kg}^{-1}$, and $1.2 \mathrm{mg} \cdot \mathrm{kg}^{-1}$ for the $1 \%$, $5 \%$, and $10 \%$ of peat moss-amended soils, respectively. The total leached $\mathrm{Pb}$ concentrations from soils amended with $1 \%$, $5 \%$, and $10 \%$ peat moss were $81.0 \%, 9.1 \%$, and $3.9 \%$, respectively, compared with that of the control soil, indicating that peat moss may be effectively used to reduce $\mathrm{Pb}$ toxicity to plants and soil organisms.

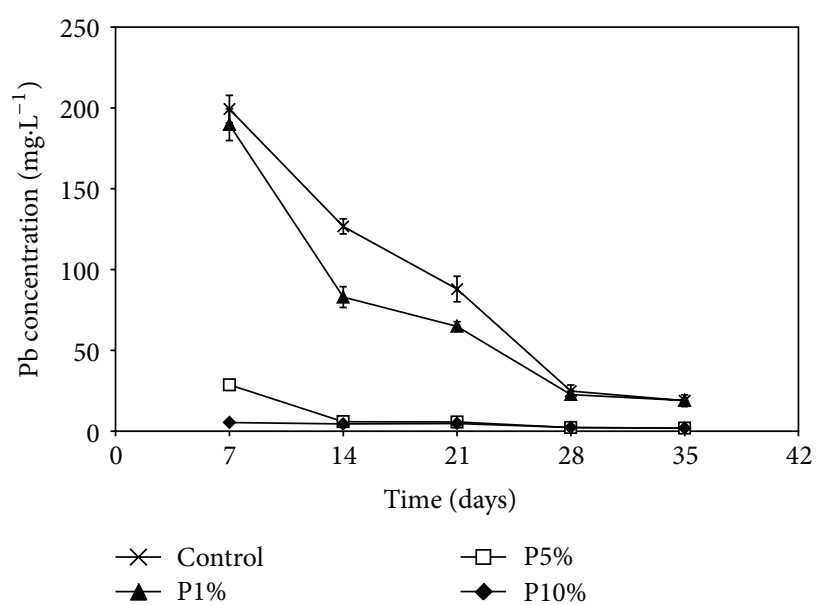

FIgURE 5: $\mathrm{Pb}$ concentration in pore water leached from $\mathrm{Pb}$ contaminated soils amended with peat moss according to time through the microcosm test (control: $\mathrm{Pb}$-contaminated soil without peat moss, $\mathrm{P} 1 \%$ : $\mathrm{Pb}$-contaminated soil with $1 \%$ peat moss, $\mathrm{P} 5 \%$ : $\mathrm{Pb}$ contaminated soil with $5 \%$ peat moss, and $\mathrm{P} 10 \%$ : $\mathrm{Pb}$-contaminated soil with $10 \%$ peat moss).

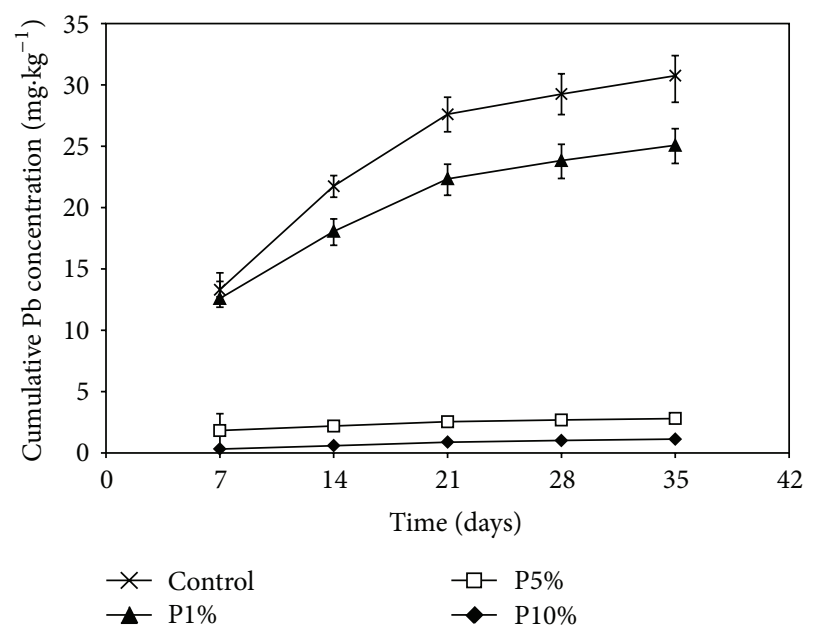

FIGURE 6: Cumulative $\mathrm{Pb}$ concentration in pore water leached from $\mathrm{Pb}$-contaminated soils amended with peat moss according to time through the microcosm test (Control: $\mathrm{Pb}$-contaminated soil without peat moss, $\mathrm{P} 1 \%$ : $\mathrm{Pb}$-contaminated soil with $1 \%$ peat moss, $\mathrm{P} 5 \%$ : $\mathrm{Pb}$ contaminated soil with $5 \%$ peat moss, and $\mathrm{P} 10 \%$ : $\mathrm{Pb}$-contaminated soil with $10 \%$ peat moss).

3.4. Batch Incubation Test. The effect of peat moss on the bioavailability of $\mathrm{Pb}$ was examined by measuring the $\mathrm{NH}_{4} \mathrm{NO}_{3}$ extractable $\mathrm{Pb}$ concentration through the batch incubation test (Figure 7). Plants can uptake heavy metal species that are weakly bound to soil constituents. Metal species weakly bound to soil particles are extractable from the soil by using dilute or neutral salt solutions of replaceable cations, such as $\mathrm{NH}_{4} \mathrm{NO}_{3}, \mathrm{MgCl}_{2}, \mathrm{CaCl}_{2}$, or $\mathrm{NH}_{4} \mathrm{OAc}$ [30]. The $\mathrm{NH}_{4} \mathrm{NO}_{3}$ extractable $\mathrm{Pb}$ concentration was $911.5 \mathrm{mg} \cdot \mathrm{kg}^{-1}$ in the control, and those were $893.2 \mathrm{mg} \cdot \mathrm{kg}^{-1}, 574.7 \mathrm{mg} \cdot \mathrm{kg}^{-1}$, and $383.5 \mathrm{mg} \cdot \mathrm{kg}^{-1}$ in the $1 \%, 5 \%$, and $10 \%$ peat moss-amended 


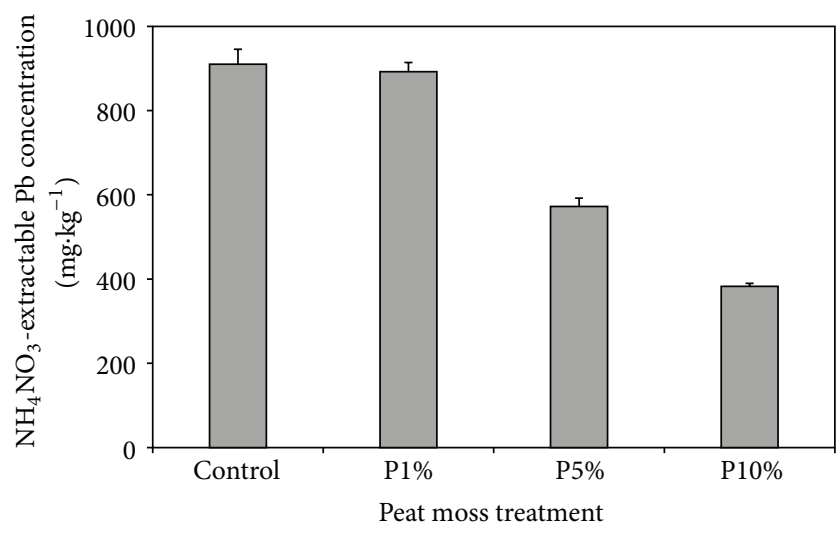

FIgURE 7: $\mathrm{NH}_{4} \mathrm{NO}_{3}$-extractable $\mathrm{Pb}$ concentration of $\mathrm{Pb}$-contaminated soils amended with peat moss (control: $\mathrm{Pb}$-contaminated soil without peat moss, $\mathrm{P} 1 \%$ : $\mathrm{Pb}$-contaminated soil with $1 \%$ peat moss, $\mathrm{P} 5 \%$ : $\mathrm{Pb}$-contaminated soil with $5 \%$ peat moss, and $\mathrm{P} 10 \%$ : $\mathrm{Pb}-$ contaminated soil with $10 \%$ peat moss).

soils, respectively. The $\mathrm{NH}_{4} \mathrm{NO}_{3}$-extractable $\mathrm{Pb}$ concentrations of the soils amended with $1 \%, 5 \%$, and $10 \%$ of peat moss were $98.0 \%, 63.0 \%$, and $42.1 \%$ of that of the control soil, indicating that the peat moss amendment decreased the bioavailable $\mathrm{Pb}$ in the soil and, therefore, might be able to reduce the potential of $\mathrm{Pb}$ accumulation in humans via the food chain. This result was also attributed to the increase of humic fractions containing functional groups that increased ionexchange or complexation with $\mathrm{Pb}$ in the soil. Kumpiene et al. (2007) also showed that the addition of peat moss significantly reduced the $\mathrm{Pb}$ leaching through a batch test [25]. An organic matter such as peat moss plays an important role in metal binding upon soil acidification.

3.5. Comparison of $\mathrm{Pb}$ Immobilization according to Experimental Method. Many studies have shown that the uptake of heavy metals by plants correlated with the available $\mathrm{Pb}$ more than with the total $\mathrm{Pb}$ concentration in the soil [31]. Therefore, it is important to reduce the available $\mathrm{Pb}$ concentration to prevent heavy metal dispersion in the ecosystem. Phytoavailable metal contents depend on the soil $\mathrm{pH}$, dissolved organic carbon (DOC), cation exchange capacity of the soil, Fe and Mn oxides content, and so forth [32]. The immobilized $\mathrm{Pb}$, which is defined as the reduced percent in the extracted $\mathrm{Pb}$ concentration in the soil amended with peat moss, can be expressed by (1)

$$
\begin{aligned}
& \text { immobilized } \mathrm{Pb}(\%) \\
& \quad=\frac{\text { Extractable } \mathrm{Pb} \text { in }(\text { control }- \text { sample })}{\text { Extractable } \mathrm{Pb} \text { in control }} \times 100 .
\end{aligned}
$$

Table 1 shows immobilized $\mathrm{Pb}$ values calculated from three types of experiments, which are the column leaching experiment for 10 pore volumes, the microcosm test for 35 days, and the batch incubation test. The values show that the immobilized $\mathrm{Pb}$ increased as the amount of peat moss increased. The immobilized lead in soils amended with $1 \%$, $5 \%$, and $10 \%$ of peat moss was $37.9 \%, 87.1 \%$, and $95.4 \%$ for
TABLE 1: Comparison of immobilized $\mathrm{Pb}$ according to the experimental method (control: Pb-contaminated soil without peat moss, $\mathrm{P} 1 \%$ : $\mathrm{Pb}$-contaminated soil with $1 \%$ peat moss, $\mathrm{P} 5 \%$ : Pb-contaminated soil with $5 \%$ peat moss, and $\mathrm{P} 10 \%$ : $\mathrm{Pb}$-contaminated soil with $10 \%$ peat moss).

\begin{tabular}{lcccc}
\hline Experimental method & $\begin{array}{c}\text { Column } \\
\text { Experiment }\end{array}$ & $\begin{array}{c}\text { Microcosm } \\
\text { test }\end{array}$ & $\begin{array}{c}\text { Batch } \\
\text { incubation } \\
\text { test }\end{array}$ \\
\hline Immobilized & $\mathrm{P} 1 \%$ & $37.93 \pm 4.98$ & $18.47 \pm 0.58$ & $2.00 \pm 1.40$ \\
$\mathrm{~Pb}(\%)$ & $\mathrm{P} 5 \%$ & $87.06 \pm 2.52$ & $90.89 \pm 0.15$ & $36.90 \pm 0.49$ \\
& $\mathrm{P} 10 \%$ & $95.44 \pm 1.49$ & $96.35 \pm 0.03$ & $57.90 \pm 0.90$ \\
\hline
\end{tabular}

the column leaching test, $18.5 \%, 90.9 \%$, and $96.4 \%$ for the microcosm test, and $2.0 \%, 36.9 \%$, and $57.9 \%$ for the batch incubation test, respectively.

The sorption mechanism of metals by the peat moss includes ion-exchange, surface adsorption, chemisorption, complexation, and adsorption-complexation of which ionexchange is considered the most prevalent mechanism [33]. Ion exchange involves electrostatic interactions between metals and charged particle surfaces. The displacement of an adsorbed metal can be associated with the strength of the adsorption. Complexation forms more stable binding than ion exchange. Thus, the metals adsorbed mainly through electrostatic physical interaction and the ion exchange can be relatively easily displaced from the peat surface. In this study, $1 \mathrm{M} \mathrm{NH}_{4} \mathrm{NO}_{3}$ solution used for the batch incubation test was the strongest extractant, and some of the weakly bound $\mathrm{Pb}$ on the peat moss might be displaced by the solution. Therefore, the experimental results showed that the peat moss reduced the mobility and toxicity of $\mathrm{Pb}$ more effectively in the column leaching and microcosm tests than bioavailability in the batch incubation test. The results of this study indicate that peat moss can be used as an effective soil conditioner to remediate $\mathrm{Pb}$-contaminated soil.

\section{Conclusions}

The effects of peat moss on the immobilization of $\mathrm{Pb}$ in $\mathrm{Pb}$-contaminated soil were investigated through three types of leaching experiments, namely, the column leaching test, microcosm test, and batch incubation test. The results of this study demonstrate that peat moss is effective in $\mathrm{Pb}$ immobilization in contaminated soil. Peat moss significantly reduced the $\mathrm{Pb}$ leaching in all of the three types of experiments. The immobilized lead of the soils amended with $1 \%, 5 \%$, and $10 \%$ of peat moss was $37.9 \%, 87.1 \%$, and $95.4 \%$ for the column leaching test, $18.5 \%, 90.9 \%$, and $96.4 \%$ for the microcosm test, and $2.0 \%, 36.9 \%$, and $57.9 \%$ for the $\mathrm{NH}_{4} \mathrm{NO}_{3}$ extraction method, respectively.

\section{Acknowledgments}

This work was supported by Korea Ministry of Environment as “The GAIA Project” (G111-17003-0043-0) and Gyeongnam National University of Science and Technology (GNTECH) Grant. 


\section{References}

[1] J. H. Park, D. Lamb, P. Paneerselvam, G. Choppala, N. Bolan, and J.-W. Chung, "Role of organic amendments on enhanced bioremediation of heavy metal(loid) contaminated soils," Journal of Hazardous Materials, vol. 185, no. 2-3, pp. 549-574, 2011.

[2] Y. Greener and J. A. Kochen, "Methyl mercury toxicity in the chick embryo," Teratology, vol. 28, no. 1, pp. 23-28, 1983.

[3] O. Strubelt, J. Kremer, A. Tilse, J. Keogh, R. Pentz, and M. Younes, "Comparative studies on the toxicity of mercury, cadmium, and copper toward the isolated perfused rat liver," Journal of Toxicology and Environmental Health A, vol. 47, no. 3, pp. 267-283, 1996.

[4] J. H. Park, N. S. Bolan, J. W. Chung, R. Naidu, and M. Megharaj, "Environmental monitoring of the role of phosphate compounds in enhancing immobilization and reducing bioavailability of lead in contaminated soils," Journal of Environmental Monitoring, vol. 13, no. 8, pp. 2234-2242, 2011.

[5] S. Raicevic, V. Perovic, and A. I. Zouboulis, "Theoretical assessment of phosphate amendments for stabilization of $(\mathrm{Pb}+\mathrm{Zn})$ in polluted soil," Waste Management, vol. 29, no. 5, pp. 1779-1784, 2009.

[6] F. M. Johnson, "The genetic effects of environmental lead," Mutation Research, vol. 410, no. 2, pp. 123-140, 1998.

[7] M. A. C. Gollmann, M. M. da Silva, A. B. Masuero, and J. H. Z. dos Santos, "Stabilization and solidification of $\mathrm{Pb}$ in cement matrices," Journal of Hazardous Materials, vol. 179, no. 1-3, pp. 507-514, 2010.

[8] K. Österberg, J. Börjesson, L. Gerhardsson, A. Schütz, and S. Skerfving, "A neurobehavioural study of long-term occupational inorganic lead exposure," Science of the Total Environment, vol. 201, no. 1, pp. 39-51, 1997.

[9] J. Sorvari, R. Antikainen, and O. Pyy, "Environmental contamination at Finnish shooting ranges-the scope of the problem and management options," Science of the Total Environment, vol. 366, no. 1, pp. 21-31, 2006.

[10] T. K. Udeigwe, P. N. Eze, J. M. Teboh, and M. H. Stietiya, "Application, chemistry, and environmental implications of contaminant-immobilization amendments on agricultural soil and water quality," Environment International, vol. 37, no. 1, pp. 258-267, 2011.

[11] S.-F. Cheng and Z.-Y. Hseu, "In-situ immobilization of cadmium and lead by different amendments in two contaminated soils," Water, Air, and Soil Pollution, vol. 140, no. 1-4, pp. 73-84, 2002.

[12] M. Uchimiya, I. M. Lima, K. T. Klasson, and L. H. Wartelle, "Contaminant immobilization and nutrient release by biochar soil amendment: roles of natural organic matter," Chemosphere, vol. 80, no. 8, pp. 935-940, 2010.

[13] S. Babel and T. A. Kurniawan, "Low-cost adsorbents for heavy metals uptake from contaminated water: a review," Journal of Hazardous Materials, vol. 97, no. 1-3, pp. 219-243, 2003.

[14] S. E. Bailey, T. J. Olin, R. M. Bricka, and D. D. Adrian, "A review of potentially low-cost sorbents for heavy metals," Water Research, vol. 33, no. 11, pp. 2469-2479, 1999.

[15] J. R. Conner, Chemical Fixation and Solidification of Hazard Wastes, Van Nostrand Reinhold, New York, NY, USA, 1990.

[16] H. S. Kim and K. H. Kim, "Physical properties of the horticultural substrate according to mixing ratio of peatmoss, perlite and vermiculite," Korean Journal of Soil Science and Fertilizer, vol. 44, no. 3, pp. 321-330, 2011.
[17] C. H. Lee and H. S. Shin, "Adsorption study of humin from peat moss with $\mathrm{Cd}(\mathrm{II}), \mathrm{Cu}(\mathrm{II})$ and $\mathrm{Pb}(\mathrm{II})$ in aqueous solution," Journal of Korean Society of Environmental Engineers, vol. 26, no. 10, pp. 1079-1085, 2004.

[18] R. H. Crist, J. R. Martin, J. Chonko, and D. R. Crist, "Uptake of metals on peat moss: an ion-exchange process," Environmental Science and Technology, vol. 30, no. 8, pp. 2456-2461, 1996.

[19] P. Fine, A. Scagnossi, Y. Chen, and U. Mingelgrin, "Practical and mechanistic aspects of the removal of cadmium from aqueous systems using peat," Environmental Pollution, vol. 138, no. 2, pp. 358-367, 2005.

[20] I. F. Grant and C. C. D. Tingle, Ecological Monitoring Methods For the Assessment of Pesticide Impact in the Tropics, Natural Resources Institute, Chatham, UK, 2002.

[21] H. Konare, R. S. Yost, M. Doumbia, G. W. Mccarty, A. Jarju, and R. Kablan, "Loss on ignition: measuring soil organic carbon in soils of the sahel, west africa," African Journal of Agricultural Research, vol. 5, no. 22, pp. 3088-3095, 2010.

[22] P. Schwab, D. Zhu, and M. K. Banks, "Heavy metal leaching from mine tailings as affected by organic amendments," Bioresource Technology, vol. 98, no. 15, pp. 2935-2941, 2007.

[23] J. H. Park, G. K. Choppala, N. S. Bolan, J. W. Chung, and T. Chuasavathi, "Biochar reduces the bioavailability and phytotoxicity of heavy metals," Plant and Soil, vol. 348, no. 1-2, pp. 439451, 2011.

[24] M. Pueyo, J. F. López-Sánchez, and G. Rauret, "Assessment of $\mathrm{CaCl}_{2}, \mathrm{NaNO}_{3}$ and $\mathrm{NH}_{2} \mathrm{NO}_{3}$ extraction procedures for the study of $\mathrm{Cd}, \mathrm{Cu}, \mathrm{Pb}$ and $\mathrm{Zn}$ extractability in contaminated soils," Analytica Chimica Acta, vol. 504, no. 2, pp. 217-226, 2004.

[25] J. Kumpiene, S. Ore, A. Lagerkvist, and C. Maurice, "Stabilization of $\mathrm{Pb}$ - and $\mathrm{Cu}$-contaminated soil using coal fly ash and peat," Environmental Pollution, vol. 145, no. 1, pp. 365-373, 2007.

[26] F. J. Stevenson, Humus Chemistry: Genesis, Composition, Reactions, John Wiley and Sons, New York, NY, USA, 1982.

[27] Y. S. Ho and G. McKay, "Pseudo-second order model for sorption processes," Process Biochemistry, vol. 34, no. 5, pp. 451-465, 1999.

[28] K. Lock and C. R. Janssen, "Effect of new soil metal immobilizing agents on metal toxicity to terrestrial invertebrates," Environmental Pollution, vol. 121, no. 1, pp. 123-127, 2003.

[29] A. L. Nolan, E. Lombi, and M. J. McLaughlin, "Metal bioaccumulation and toxicity in soils: why bother with speciation?" Australian Journal of Chemistry, vol. 56, no. 2-3, pp. 77-91, 2003.

[30] R. P. Narwal, B. R. Singh, and B. Salbu, "Association of cadmium, zinc, copper, and nickel with components in naturally heavy metal-rich soils studied by parallel and sequential extractions," Communications in Soil Science and Plant Analysis, vol. 30, no. 7-8, pp. 1209-1230, 1999.

[31] G. S. R. Krishnamurti and R. Naidu, "Speciation and phytoavailability of cadmium in selected surface soils of South Australia," Australian Journal of Soil Research, vol. 38, no. 5, pp. 991-1004, 2000.

[32] K. R. Kim, G. Owens, R. Naidu, and K. H. Kim, "Assessment techniques of heavy metal bioavailability in soil-A critical review," Korean Journal of Soil Science and Fertilizers, vol. 40, no. 4, pp. 311-325, 2007.

[33] P. A. Brown, S. A. Gill, and S. J. Allen, "Metal removal from wastewater using peat," Water Research, vol. 34, no. 16, pp. 3907$3916,2000$. 

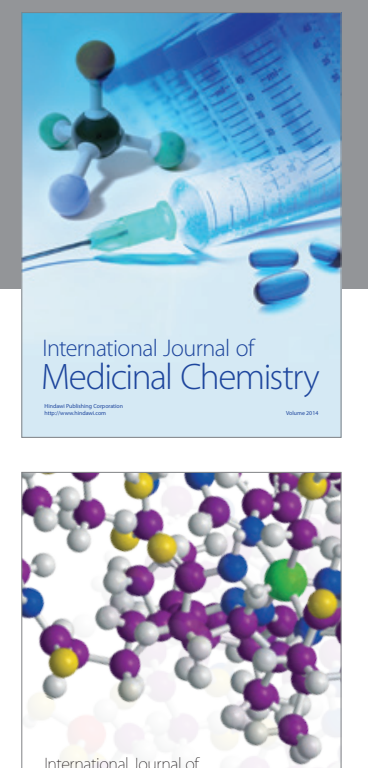

\section{Carbohydrate} Chemistry

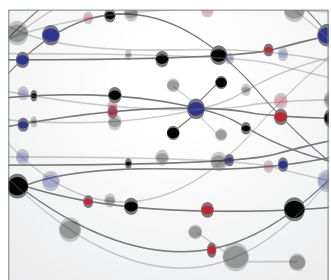

The Scientific World Journal
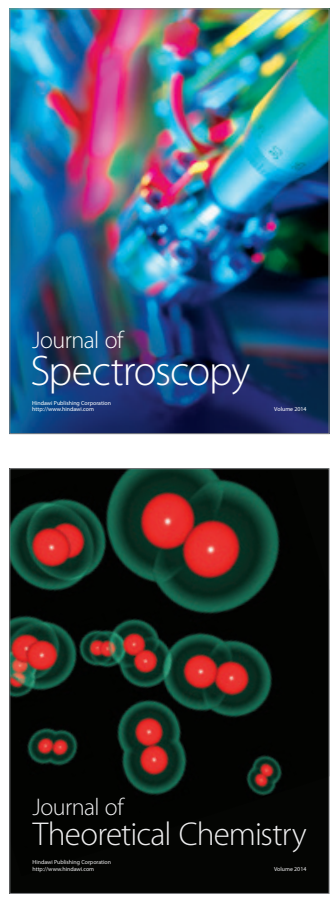
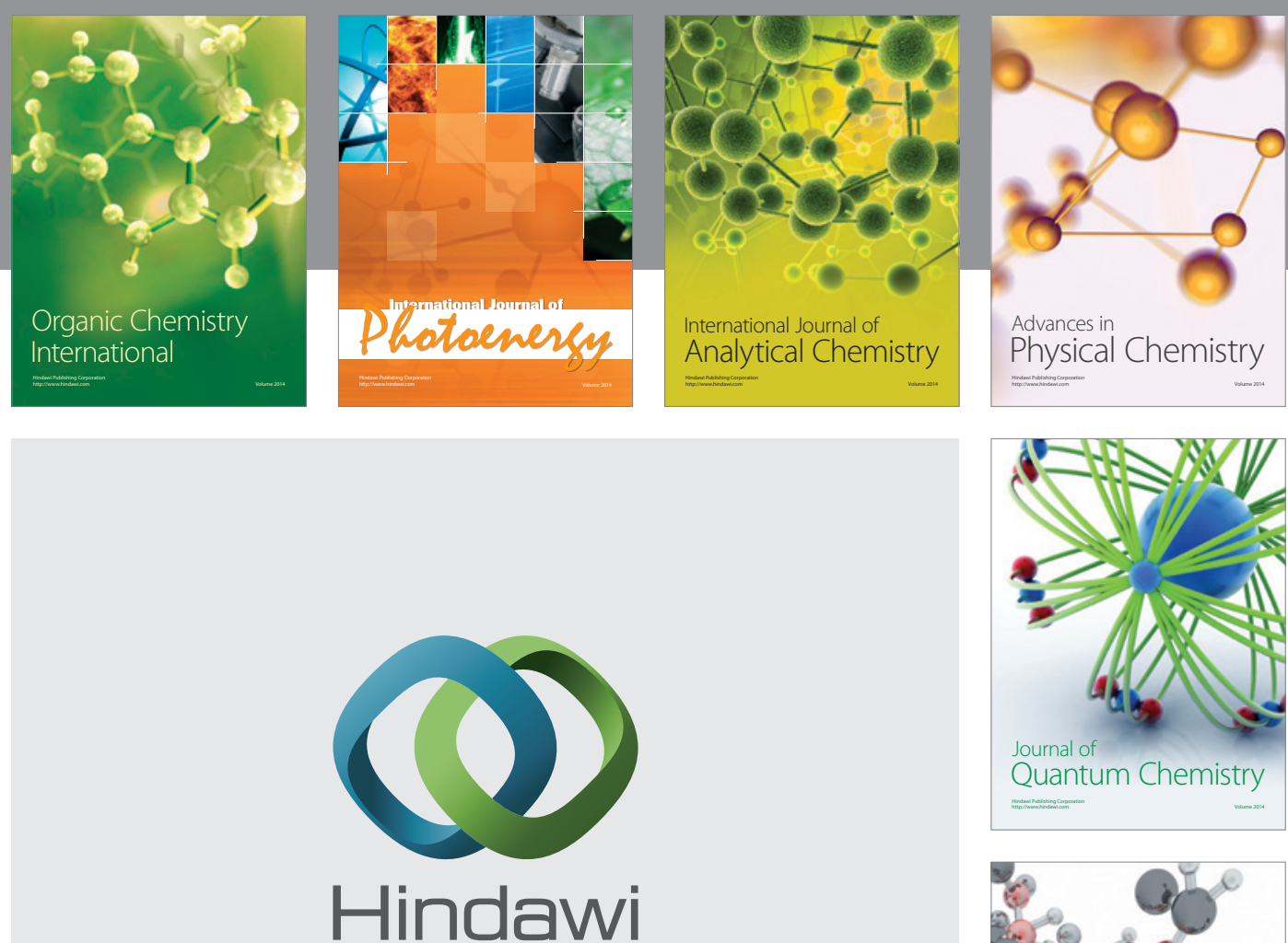

Submit your manuscripts at

http://www.hindawi.com

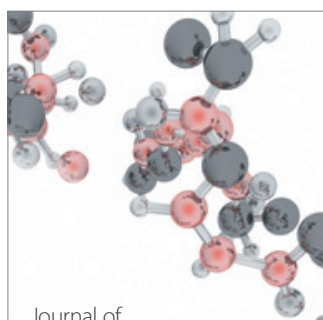

Analytical Methods

in Chemistry

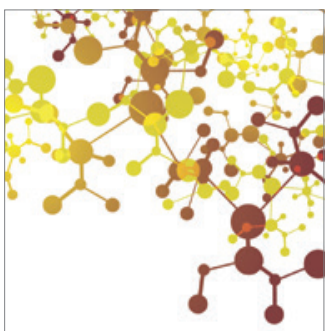

Journal of

Applied Chemistry

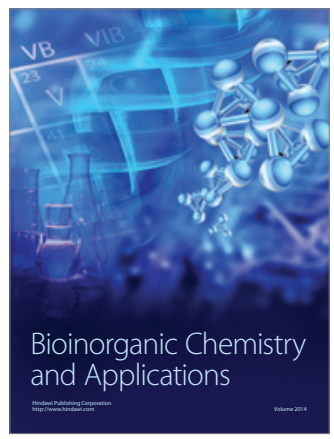

Inorganic Chemistry
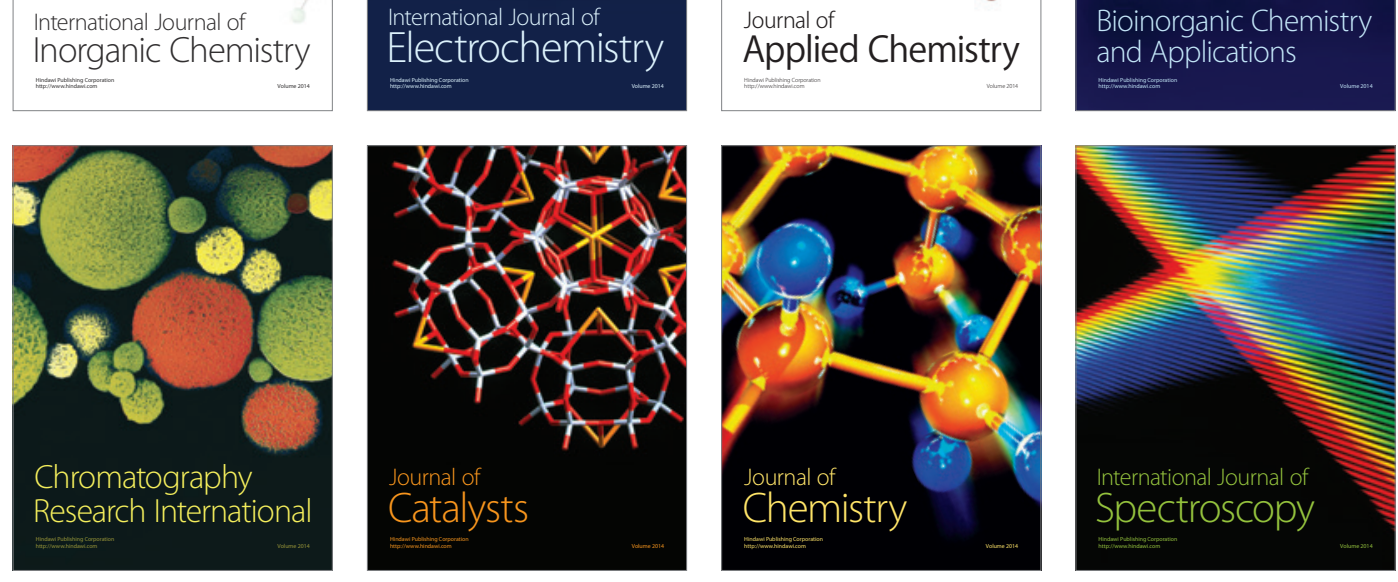